\title{
Advocacy Coalitions Along the Domestic-Foreign Frontier: Globalization and Canadian Climate Change Policy
}

Karen T. Litfin

\begin{abstract}
With its emphasis on shared beliefs and the advocacy use of knowledge within policy subsystems, the advocacy coalition framework $(A C F)$ is ideally suited to the study of environmental policy. Yet the $A C F$ has generally been applied in a domestic context. This article argues that the twin phenomena of economic globalization and the internationalization of environmental affairs are blurring the distinction between some policy subsystems and the international arena. Thus, advocacy coalitions should be understood as operating increasingly along "the domestic-foreign frontier." In the case of Canada's efforts to develop a coherent climate change policy, the boundaries between political levels have been blurred as local and provincial actors come to understand themselves as players in a global game. This dynamic is exacerbated by Canada's unique constitutional division of authority, which delegates significant autonomy to the provinces on natural resource and energy issues.
\end{abstract}

The advocacy coalition framework (ACF) developed by Sabatier and Jenkins-Smith usefully moves the study of public policy beyond the traditional and overly mechanical "stages" approach. With its emphasis both on shared beliefs as the glue of politics and on the advocacy use of knowledge and analysis within policy subsystems, the ACF is especially applicable to the study of environmental policy. Yet the ACF has been developed and generally applied within a disciplinary context that views policy formation as an essentially domestic-level process occurring within states. According to the ACF, policy shifts are the result of changes external to the policy subsystem, including "dynamic system events" at the international level (Sabatier \& Jenkins-Smith, 1993, pp. 22-23). This article argues that the twin phenomena of economic globalization and the internationalization of environmental affairs are blurring the distinction between at least some policy subsystems and the international arena. Consequently, the ACF can be enriched by the recent literature in international relations theory that attempts to grapple with the convergence of domestic and foreign affairs. On that basis, this article contributes to bridge-building between "the two solitudes" (Doem, Pal, \& Tomlin, 1996, p. 5)-international relations and policy studies-by examining Canadian climate change policy over the past decade.

In many ways, the dynamics of Canadian climate change policy are ideally suited to this exercise. The advocacy coalitions within the policy subsystem, along with their causal and normative beliefs about climate change, can be mapped out fairly easily. Furthermore, the combination of Canada's unique constitutional division of powers between the federal government and the provinces, and its close ties to its far more powerful and environmentally influential neighbor to the south, mean that global-local linkages, which inevitably obscure the boundary between domestic and foreign affairs, are likely to 
Symposium on Canadian Environmental Policy: Litfin

be particularly evident. Moreover, climate change is by definition an internationalized environmental issue, even though both its causes and effectssocioeconomic, ecological, and political - are local and regional in character.

Because this case is an easy one for my argument that some advocacy coalitions can be understood as operating "along the domestic-foreign frontier" (Rosenau, 1997), this article should be interpreted more as a heuristic test case and a bridge-building exercise rather than as any attempt to present a conclusive argument for the universal internationalization of the ACF. Nonetheless, the apparently inexorable process of globalization suggests that the number of policy issues requiring an expanded conceptualization of the ACF may be rising. Indeed, Canada's shift from an activist climate change position a decade ago to a more cautious one by 1997 can be explained in part by economic globalization, the effects of which are felt acutely at the provincial level.

While a varied literature in international relations has focused on the linkages between domestic and foreign affairs, I draw from James Rosenau's notion of "the frontier" to highlight the convergence, rather than simply the mutual interplay, between traditionally separated levels of politics. In the 1970s and 1980s, "second image" and "second image reversed" literatures explored, respectively, the domestic causes of foreign policy and the international sources of domestic policy (Gourevitch, 1978; Katzenstein, 1983). More recently, the twolevel games approach proposes an interactive model by viewing national negotiators as constrained simultaneously by domestic and international factors (Evans, Jacobson, \& Putnam, 1993; Putnam, 1988). All of these approaches, however, presume the fundamental domestic/foreign divide.

Rosenau's notion of "the frontier" explicitly challenges that premise. "The frontier" is envisioned "as a widening field of action, as the space within which world affairs unfold, as the arena in which domestic and foreign issues converge, intermesh, or otherwise become indistinguishable within a seamless web-what might be called the politics of the Frontier" (Rosenau, 1997, p. 5). Most importantly, the identities and interests of "domestic" economic and political actors increasingly are being shaped by global forces. The claim of this article is that Canadian climate change policy is understood best in terms of conflicting advocacy coalitions acting along the domestic-foreign frontier. Such an understanding requires taking into account the global motives and context of domestic actors in advocacy coalitions as well as recognizing that foreign actors also participate in advocacy coalitions.

The following section explores the ACF and the notion of the frontier, making two interrelated arguments: that each analytical framework is well suited to international environmental policy issues, and that they can be combined usefully. The third section presents the case study of Canada's climate change policy. Within that section, 1 first give an overview of the climate change issue in the Canadian context, after which I lay out two "Canadian conundrums" pulling the federal government from within and without: the unique legal structure of federal/provincial relations and the constraining influence of considerations involving the United States. With this background, I offer an overview of Canadian climate change policy from 1988 to 1997 . The final section analyzes the case study in terms of a globalized interpretation of advocacy coalitions operating along the domestic-foreign frontier. 


\title{
Expanding the ACF
}

The twin objectives of the advocacy coalition framework, developed by Sabatier and Jenkins-Smith (1993; see also Sabatier, 1988), are: (a) to add more theoretical rigor to the policy literature by devising testable propositions regarding policy change and continuity, and (b) to address the empirical shortcomings of early approaches based upon distinct stages in the policy process. In particular, Sabatier and Jenkins-Smith (1993) noted that the stages of agenda setting and fact finding frequently are mingled, that the legalistic top-down approach of the stages model is often at odds with actual practice, and that policy evolution involves multiple interacting cycles (rather than a single policy cycle) among multiple levels of government (Sabatier \& Jenkins-Smith, 1993, pp. 2-4). Contrary to the stages approach, the ACF highlights "the advocacy use of analysis," or the politicization of knowledge, and the cross-culting nature of policy coalitions. Advocacy coalitions within a policy subsystem consist of

\begin{abstract}
"actors from a variety of public and private institutions at all levels of government who share a set of basic beliefs (policy goals plus causal and other perceptions) and who seek to manipulate the rules, budgets, and personnel of governmental institutions in order to achieve these goals over time" (Sabatier \& Jenkins-Smith, 1993, p. 5).
\end{abstract}

Because core beliefs, the "glue" that holds together advocacy coalitions, do not change easily, the ACF is more a theory of continuity than a theory of change (Mintrom \& Vergari, 1996). Policy outcomes are constrained by "stable system parameters," which can include social structures and constitutional rules. Policy change over time is a function of events outside the subsystem, which could include international, socioeconomic, scientific, or electoral shifts. Policyoriented learning across coalitions, in which one or both coalitions alter their core beliefs, is facilitated by: (a) a moderate level of conflict, (b) an issue that is tractable analytically, and (c) the presence of a professionalized forum in which experts from competing coalitions must justify their claims before their peers (Sabatier \& Jenkins-Smith, 1993, pp. 48-55).

The ACF is ideally suited to the analysis of environmental policy processes. First, environmental problem solving usually involves multiple agencies and levels of government and is driven by coalitions of diverse stakeholders. Second, more than other issues, environmental policy is driven by technical and analytical knowledge. Third, because the core beliefs of clashing coalitions generally are both deeply held and fundamentally incommensurable, scientific information is politicized easily, particularly in more adversarial policy systems. Indeed, as I have argued elsewhere, the politicization of science is a hallmark of the environmental policy process (Litfin, 1994). Finally, despite the fact that the environmental policy agenda often is science-driven, policy outcomes are constrained by socioeconomic and political structures. Given the good fit between the ACF and environmental issues, it is not surprising that the framework has been applied so frequently in this arena: to air pollution in the United States (Sabatier, 1993); to Califomia water politics (Munro, 1993); to offshore oil and natural gas drilling (Jenkins-Smith \& St. Clair, 1993); and to environmental policy at Lake Tahoe (Sabatier \& Brasher, 1993). Yet, reflecting the domestic bias of the field of policy studies, the ACF has been applied mostly to domestic (in particular, U.S.) policy issues. 
In the face of the rapid internationalization of environmental politics, a greater effort should be' made to broaden the ACF's applicability. Each of the aforementioned four dimensions that make the ACF ideally suited to the environmental arena applies to transboundary and global problems as well. More importantly, increased economic, social, and ecological interdependence means that domestic environmental politics are less insulated than ever from the intemational system. In all parts of the world, the policy agendas of domestic environmental agencies are determined increasingly by international events and processes (Schreurs \& Economy, 1997). Simultaneously, environmental nongovernmental organizations (NGOs) are both proliferating numerically and developing more extensive transnational linkages (Wapner, 1996). A "global civil society" seems to be emerging that links local and global networks of knowledge (Lipschutz, 1996). The impact of these and other developments is reconfiguring state sovereignty, so that the utility of earlier approaches that took the self-contained state and its agencies as the basic units of decisionmaking and policy action is declining (Litfin, 1997, 1998).

While the rigid separation of national and international affairs is problematic for a host of issues, it is especially so in the realm of global ecology. Increasingly, local environmental problems (desertification, air and water pollution) demand global strategies, and global environmental problems (loss of biodiversity, climate change, ozone depletion) demand local action (Dyer, 1994). Over the past three decades, the environmental policy agenda has been globalized and internationalized, moving from local and regional air quality issues in the 1970s to global problems like ozone depletion and climate change requiring international cooperation.

The twin dynamics of globalization and internationalization are driving an ever-wider range of policy questions. Globalization is a technological and economic process driven by the information revolution, capital mobility, flexible worldwide production, and growing ecological interdependence. Internationalization, which is both prior to and stimulated by globalization, refers to "a process by which various aspects of policy or policy making are influenced by factors outside national territorial boundaries" (Doern, Pal, \& Tomlin, 1996, p. 3). While these two dynamics do characterize contemporary environmental trends, they also connote a sense of integration that needs to be tempered by a recognition that these forces also enhance the salience of various subnational actors. Roland Robertson's term, "glocalization," captures the mutually reinforcing character of globalizing and localizing trends, while Rosenau's term, "fragmegration," suggests "the simultaneity and interaction of the fragmenting and integrating dynamics that are giving rise to new spheres of authority and transforming the old spheres" (Robertson, 1995; Rosenau, 1997, p. 38). Thus, traditional boundaries become more porous as the unitary sovereign state of international relations-perhaps always something of an ideal type-is pulled from within and without, even as the policy process, traditionally considered a domestic affair, involves a wider range of actors within and beyond the state. Policymaking and implementation increasingly are occurring along the domestic-foreign "frontier."

Consequently, it makes sense to expand the ACF, which has contributed to our understanding of domestic policy processes, into the global arena. There are several advantages in doing so. First, such a move is consistent with the fact that local and regional actors often view themselves as deeply embedded in global processes, formulating their beliefs within a social context that includes the globalization of production and the radically increased mobility of capital and 


\section{Policy Studies Journal, 28:1}

goods. Second, given this embeddedness of actors across the political spectrum in global social, economic, and environmental processes, policy coalitions are, to a greater extent than ever, transnational in character. For instance, local utilities, labor unions, and municipalities may find themselves actively engaged in policy debates on global warming because of their beliefs about the impact of globalization on their material welfare. Finally, although adopting a wider understanding of the policy system does not exactly endogenize international sources of policy change (which thereby would enable the ACF to offer an explanation of change as well as continuity), this broader understanding at least does have the effect of making those sources of change more visible and more comprehensible in terms of the self-understandings of the policy actors themselves.

In the case of Canadian climate change policy, the primary advocacy coalitions, even when they appeared as national and subnational actors, very much understood themselves as thoroughly embedded in a global context. For the environmentalist coalition, that globalized understanding was based upon primarily causal beliefs about Earth's climatological systems and moral beliefs about the special environmental responsibility of affluent peoples. For the advocates of a go-slow approach, their globalized understanding was rooted primarily in causal beliefs about global economic competitiveness and, for some, in a general skepticism regarding the scientific predictions and perhaps moral beliefs about the primacy of short-term economic welfare over long-term environmental objectives. Given these globalized self-understandings of the opposed advocacy coalitions, their positions and actions are described best as taking place along the domesticforeign frontier. Global considerations became more salient over time, particularly with the heightened concerns for economic competitiveness. The outcomes, I will argue, are explainable partially in terms of two system parameters: Canada's unique federal/provincial structure and the structural power of the United States.

In the following section, I lay out the climate change issue as it affects Canada, the specific structural factors that constrain federal responses, and the history of those responses from 1988 to the present.

\section{Canadian Climate Change Policy: From Global Leadership to Follow-the-Leader}

\section{Climate Change in Canada: Sources and Impacts}

A scientific consensus has developed since the late 1980s that the accumulation of greenhouse gases (GHG)-primarily carbon dioxide, but also methane, chlorofluorocarbons (CFCs), and nitrous oxide - in the earth's atmosphere will change the world's climate significantly sometime in the next century (Intergovernmental Panel on Climate Change, 1990; Schneider, 1989). In 1995, the Intergovernmental Panel on Climate Change (IPCC), representing the work of over 2,000 atmospheric scientists, concluded for the first time that "the balance of evidence suggests a discernible human influence on global climate" (Intergovernmental Panel on Climate Change, 1995, p. 1). Although many uncertainties remain regarding timing and regional impacts, climate change thus was catapulted from a distant threat to current reality. By now, the litany of likely effects is familiar to most readers: rising sea levels, shifting agricultural and forest patterns, migration of species, and an overall global warming accompanied by more severe weather extremes. 
Symposium on Canadian Environmental Policy: Litfin

While there was some early speculation that Canada, with its relatively cold climate, might be a net beneficiary as its winter heating requirements diminished and its growing season lengthened, these speculations soon were counterbalanced by other factors. Predicted warming trends, for instance, could displace Canada's extensive boreal forests with grassland ecosystems (Government of Canada, 1991, pp. 18-22). More alarmingly, with the longest coastline of any country in the world, Canada would suffer disproportionately from inundation of waterfront areas and loss of wetlands associated with rising sea levels. Other effects of climate change in Canada would include thawing of permafrost, with ensuing erosion, a decline of marine fisheries, and a decrease in freshwater supplies (Atkinson, 1994; Government of Canada, 1991, pp. 19-22).

On the one hand, Canada has clear reason to be concerned about climate change; on the other hand, as the world's number-two source of GHG emissions per capita, Canada also could be wary of mitigation strategies. Moreover, the degree of wariness is likely to vary among the provinces. Although no Canadian province has argued that it stands to benefit from global climate change, policies to reduce GHG emissions would have dramatically different regional impacts. Most severely impacted would be Ontario, with its large industrial base, and fossil fuel-rich Alberta. From the beginning Alberta has voiced the strongest opposition among the provinces to federal proposals to reduce GHG emissions, and has been a major player in Canadian climate change policy formulation.

Nonetheless, the federal government assumed a role of international leadership in conferences and negotiations leading up to the Framework Convention on Climate Change at Rio in 1992. As a wealthy, technically advanced country with one of the highest per capita emission rates, Canada claimed "a special responsibility to lead by example" (Government of Canada, 1991, pp. 22-26). This moral belief, along with causal beliefs linking GHG emissions to the perils of climatic change, were the core beliefs uniting together the environmentalist advocacy coalition, a coalition made up of environmental NGOs, key leaders within the Department of Environment, and some scientists.

\section{Canadian Conundrums: Domestic and International Structural Factors}

Environmental policymaking in Canada is conditioned heavily by two sets of structural factors: Canada's unique constitutional division of authority and its sensitivity to events in the United States. Although these two sets of structural factors are extremely significant in Canadian environmental policy formation and implementation, it is important to note that they are not alldetermining. Their salience varies with specific factors exogenous to the policy subsystem-most importantly, public opinion and trends in the global economy.

Domestically, the Canadian government is constrained by its distinctive constitutional arrangement, which gives considerable authority to the provinces. Energy policy and most public land, for instance, fall under provincial jurisdiction. Despite the constitutional ambiguity, the Supreme Court-the final arbiter on jurisdictional issues-generally has granted the federal government jurisdiction on environmental issues. As Kathryn Harrison (1996, p. 54) has argued, "Constitutional uncertainty persists primarily because the federal government has taken a narrow view of its own powers." She found that during periods when the environment attracts public attention the federal government adopts a more activist stance, whereas during normal periods of low salience its electoral incentives lead 
it to profess inadequate jurisdiction and thereby deflect demands for environmental protection to the provinces. Because provincial jurisdiction is tied closely to exploitation of natural resources, the provinces tend to claim jurisdiction even during periods of low public salience (Harrison, 1996, pp. 29-30), and because federal-provincial conferences operate by consensus, policy outcomes tend to gravitate to the lowest common denominator.

Harrison's general explanation for the oscillating pattern of federal activism in environmental policy makes sense for Canadian climate change policy from 1988 through 1997, which includes a period of extremely high salience (1988-92) and a period of declining public concem over environmental issues (1993-97) (Harrison, 1996). While the Canadian government assumed a prominent role as an intemational leader on the climate change issue during the first period, by 1997 it essentially was mirroring the laggardly position of the United States. Yet public opinion should not be taken as the sole independent variable here. As we shall see, a generalized emphasis on global economic competitiveness, stimulated by international free trade initiatives, provided the backdrop for Canada's climate change debates.

We also should note that the federal government's tendency to defer to the provinces has been amplified in the 1990 s by Quebec separatism. Having survived Quebec's last independence referendum by a tiny margin, the federal government is trying to demonstrate its commitment to decentralization, with the environment being a lead policy area in that respect. Moreover, because the federal government has reined in its deficit in large part by cutting transfers to the provinces, the latter are increasingly resistant to any perception of federal encroachment in what they see as provincial matters. ${ }^{1}$

Intemationally, Canada's constitutional ambiguity on environmental questions reverberates in its treaty negotiations. After achieving independence with respect to judicial review and foreign policy in 1931, Canada's Judicial Committee, acting as the final arbiter of the constitution, declared that the federal Parliament and provincial legislatures were sovereign in their separate constitutional spheres, so that the federal government could not guarantee implementation of treaties where the provinces had jurisdiction. Thus, "the Canadian government, humiliatingly, must insert what are called federal-state clauses into treaties which it signs that affect provincial jurisdiction-clauses that in effect say that the government of Canada cannot guarantee implementation" (Valpy, 1997). The federal government's awkward position was particularly evident at the Kyoto climate change conference, where provinces, industry, and NGOs served on the conflict-ridden Canadian delegation. Indeed, officials from Alberta and Saskatchewan hinted publicly that their provinces may honor neither the standards set by the federal government nor the Kyoto Protocol (Mcilroy \& Laghi, 1997).

Canada's autonomy on international environmental matters is also constrained greatly by its close relations with the United States. As Hoberg (1996) has argued, Canada's commitment to free trade means that the federal government must develop its environmental policies with an eye to its trading partners-especially the United States. He concludes that, where the United States is concemed, Canada is more of a "policy taker" than a policymaker. Hoberg's conclusion is substantiated by Canada's "follow-the-leader" approach to climate change at Kyoto in 1997. We should note that, while Canada's role as "policy taker," reacting to the United States, may be interpreted as a function of material 
Symposium on Canadian Environmental Policy: Litfin

economic factors, it also can be incorporated into the ACF in terms of the core beliefs of policy actors.

In sum, the structural factors constraining Canada's international environmental policy are its unique federal/provincial constitutional arrangement and its strong socioeconomic ties to the United States. Taken together, these factors go far toward explaining why Canada retreated from its position of leadership at Rio, adopting only a slightly greener stance than the United States at Kyoto.

\section{Canadian Climate Change Policy from Rio to Kyoto}

From 1988 to 1992, the Canadian government was an outspoken advocate of environmental protection on the world scene. The simultaneous end of the Cold War and growth in ecological awareness fostered a strong sense of Canadian internationalism and environmental leadership. In 1987, Canada hosted the highly visible conference that led to the signing of The Montreal Protocol on Substances That Deplete the Ozone Layer. The 1988 Toronto Conference on the Changing Atmosphere, held during a sweltering drought that spread across much of Europe and North America, first put climate change on the international policy agenda. Although scientists believed that a $60 \%$ reduction in GHG emissions would be required to stabilize the world's climate, a position that was reiterated by the IPCC in 1990, their "Toronto target" proposed a $20 \%$ reduction of 1988 levels by 2005 as a politically more feasible goal (Intergovernmental Panel on Climate Change, 1990). Riding a wave of intense public concern at the Toronto conference, Conservative Prime Minister Brian Mulroney called for an international "law of the atmosphere," analogous to the Law of the Sea, to protect the world's climate (Knox, 1997). The following year, Canada and 23 other countries signed the Hague Declaration, calling for a global convention on climate change (Canadian Council of Ministers of the Environment, 1990, p. 11).

During this same period, the Canadian Parliament recommended a 20\% reduction of GHG emissions from 1988 levels by the year 2005, and Mulroney's activist Environment Minister, Lucien Bouchard, declared publicly that Canadians should be prepared to change their lifestyles radically to combat global warming (Richardson, 1993, p. 11). In 1989, Bouchard, buoyed by public opinion that favored federal jurisdiction on environmental matters, obtained cabinet approval to develop a 5-year Green Plan for Canada. As the secretive drafting process drew on, rumors of a carbon tax caused alarm among industrialists and some provincial leaders - especially Alberta (Hoberg \& Harrison, 1994). Thus, from early on in the climate change policy debates, it was clear that federal taxing measures would meet with considerable provincial resistance. Although one of the Green Plan's objectives was the stabilization of GHG emissions at 1990 levels by the year 2000 , a target that was reiterated at Rio, the Plan contained little in the way of substantive policies and financial commitments.

While the Green Plan's climate change objective was formulated first at the federal level, the National Action Strategy on Global Warming, enunciating an identical objective, was released in November 1990. The National Action Strategy was an intergovernmental document "prepared under the auspices of parallel steering committees of Environment and Energy Deputy Ministers" (Canadian Council of Ministers of the Environment, 1990, p. ii). Thus, the goal of stabilizing GHG emissions at 1990 levels by 2000 was not simply a federal rhetorical ploy to demonstrate international leadership, but appears to have been a 
policy that enjoyed wide support among provincial governments and even in the energy sector.

Having said this, we must note that the National Action Strategy offers only vague proposals for actually achieving its objective and is laced with what in hindsight might be called escape clauses. Each mention of the goal of stabilizing GHG emissions, for instance, is followed by the disclaimer, "This is a national target and does not pertain to specific regions or sectors" (Canadian Council of Ministers of the Environment, 1990, pp. v, 1, 21). Similarly, the need for provincial approval is evident in the numerous statements that global warming policies should be codified in federal/provincial agreements. The National Action Strategy is also sensitive to the other set of structural constraints affecting Canadian environmental policy: the global economy, and especially ties to the United States. The document twice calls attention to the fact that measures to reduce GHG emissions could diminish Canada's economic competitiveness if its "major trading partners, including the United States, do not undertake similar actions" (Canadian Council of Ministers of the Environment, 1990, pp. 9, 20). By 1997, these two sets of concerns-provincial jurisdiction and global economic competitiveness, mentioned only as caveats in 1990 came to occupy center stage in the climate change policy debates.

Nonetheless, in the heady internationalist climate of the early $1990 \mathrm{~s}$, Canada pressed its stabilization position at the 1992 Earth Summit. Taking little heed of U.S. Opposition under the Bush administration to any emission controls on GHGs, Canada positioned itself alongside Western European proposals to stabilize or modestly reduce GHG emissions sometime around the year 2000. Canada highlighted its identity as "a wealthy, technically advanced country having one of the highest per capita carbon dioxide emissions in the world" and thereby having "a special responsibility to lead by example" (Government of Canada, 1991, pp. 22-26). Moreover, in strong contrast to the U.S. position regarding developing countries, Canada pushed for additional financial assistance to help them reduce their GHG emissions. Opposition by the United States to binding targets to reduce GHG emissions and to additional aid to developing countries produced a rather watered-down Framework Convention on Climate Change (FCCC) at Rio.

The treaty, ratified by over 100 countries, came into force in March 1994, committing industrialized countries to a nonbinding goal of stabilizing GHG emissions at 1990 levels by 2000 . All countries, including developing countries, were asked to report regularly on their emissions. Most importantly, parties to the FCCC agreed to hold a series of follow-up Conferences of the Parties (COP) to assess their progress in stabilizing GHG emissions and to monitor the need for additional steps. The first two conferences were held in Berlin in April 1995 and Geneva in July 1996. At the third COP, held in Kyoto in December 1997, the parties agreed to binding restrictions on GHG emissions.

At least initially, Canada seemed to take its Rio commitments seriously. In 1993, the federally funded Canadian Global Change Program released a report entitled Canadian Options for Greenhouse Gas Emissions Reduction [COGGER] (Robinson et al., 1993). The study found that not only would it be feasible and cost-effective to meet the interim target of stabilization at 1990 levels by 2000 , but that a $20-40 \%$ energy savings could be achieved by 2010 if best technologies were used. The report considered a range of policy instruments, including a carbon tax, tradable permits, shifts in government subsidies, and incentives to encourage efficiency. Remarkably, the COGGER Report took seriously the IPCC's estimate 
Symposium on Canadian Environmental Policy: Litfin

that a $60-80 \%$ absolute reduction would be required to stabilize global atmospheric concentrations of GHG. Finally, the report highlighted the position of international leadership taken at Rio: "Canadian policies to address global warming should set the standard for other countries" (Robinson et al., 1993, p. 23). Like previous Canadian initiatives on global climate change, however, the COGGER report fell victim to the dual pressures of domestic politics and economic globalization; only the most innocuous of its proposals were ever implemented.

Interestingly, Canada's strongest environmental positions were staked out by the Conservative Party from 1988 through 1993. While in the opposition, the Liberal Party advocated enhanced federal authority on environmental matters; its 1993 election platform included a commitment to reduce GHG emissions $20 \%$ by 2005. Yet these positions did not reflect the Liberals' core beliefs, which were rather centered on trade and economic competitiveness. Thus, after being elected into office in November 1993, the Liberals abandoned their commitment to reduce GHG emissions and ceded greater environmental authority to the provinces, hoping in particular to establish a stronger base of support in the more resourcedependent Western provinces (interviews with Chris McDermott, policy advisor, Department of Environment [Ottawa], and Louise Comeau, former director of Sierra Club Canada and member of the Canadian delegation to Kyoto). A top priority for the Liberal government was to reduce Canada's federal budget deficit, an objective closely linked to global economic competitiveness since taxation is believed to slow economic growth. This included drastically cutting Environment Canada's budget. The $\$ 3$ billion Green Plan, which was "an opportunity for the federal government to buy its way into the environment" (Harrison, 1996, p. 157), was canceled.

Simultaneously, the exigencies of Quebec separatism and festering provincial concern over federal environmental initiatives taken between 1988 and 1992 led the Liberal government to launch "environmental harmonization talks" with the provinces. According to proponents, harmonization would reduce overlap and duplication between the federal and provincial governments. For opponents, harmonization would mean "a race to the bottom" and "federal-provincial, behindclosed-doors dealmaking" ("NGOs Urge Ministers," 1996). With respect to international negotiations, the implications of harmonization were clear: Canada's positions would require provincial support. As we shall see, the international climate change negotiations provided a rather embarrassing test case in this regard.

At the First Conference of the Parties (COP1), held in Berlin in April 1995, Canada submitted its National Action Program on Climate Change (Environment Canada, 1995), allegedly a blueprint for achieving its stabilization target. The report maintains that "Canada is working to meet its current commitment to stabilize GHG emissions at 1990 levels by the year 2000 ," but admits that "current forecasts predict that Canada's GHG emissions could be in the order of 13\% above 1990 emissions by the year 2000" (Environment Canada, 1995, p. 1-1). The primary mitigation strategy contained in the National Action Program is the Voluntary Challenge and Registry, endorsed by all federal, provincial, and territorial energy and environment ministers, which "will encourage all sectors to explore cost-effective actions ... free from government regulatory requirements" (Environment Canada, 1995, p. 3.2-1). Secondarily, the federal government sought to set an example by committing itself to reducing GHG emissions in its own operations. 
The "Berlin Mandate" called for strengthening the Rio commitments and for a legally binding protocol to be adopted at the third conference in Kyoto. By the Berlin meeting, Canada had backpedaled significantly on its Rio commitments, and found itself siding with the United States (Paterson, 1996, p. 69). The "Geneva Declaration," adopted at the second COP, called for an acceleration of the "Berlin Mandate" talks, and, most importantly, endorsed the IPCC's 1995 conclusion that human-induced climate change had become a reality (Intergovernmental Panel on Climate Change, 1995, p. 1). At the Denver G-7+1 Economic Summit, in June 1997, Canada joined the United States and Japan in defeating European proposals for reducing GHG emissions by $20 \%$ by 2010 . In the end, summit leaders called vaguely for reductions of GHG emissions by 2010 (Environment Canada, 1997, p. 3). Given that Canada already had "failed spectacularly to meet its own target for cuts in emissions" (Knox, 1997, p. 1), even meeting this tepid target could prove challenging.

As the Kyoto meeting approached, Canadian environmental NGOs consistently drew attention to the federal government's abandonment of its Rio pledge, as well as to the Liberal Party's abandonment of its own election platform. The Sierra Club of Canada, for instance, gave the government an " $F$ " grade on its annual 1997 "Rio Report Card," calling attention to ominous trends in Canada's weather patterns (Sierra Club of Canada, 1997, p. 3). NGO criticism of the Canadian government, however, was not limited to the domestic arena, but was broadcast internationally. Two days before the opening of the Kyoto conference, Canadian environmental activists drew attention to the $13 \%$ rise in Canadian GHG emissions since 1990 in a story circulated widely in U.S. newspapers. "It's a national disgrace, of course, not at all the sort of thing one expects from Canada the good and green," said one NGO leader, "Except that 'good, green Canada' is mostly myth" (Nickerson, 1997, p. A11). Throughout the climate change debates, Canada's environmental NGOs have operated along the domestic-foreign frontier, allied with transnational NGOs like the Climate Action Network, prodding the federal government, scolding the provinces, and broadcasting their views to both domestic and international publics (see Climate Action Network, 1997).

Despite the NGOs' efforts, the devolution of environmental authority to the provinces was being augmented by global forces. Whereas the provinces once defended their jurisdiction on environmental matters on the basis of domestic competitiveness and constitutionality, by 1996 the arguments against federal regulatory proposals to reduce greenhouse emissions were framed primarily in terms of global competitiveness. In one paper on climate change policy, an official from Alberta's Department of Energy argued that because deregulation of the energy sector is under way in most Organization for Economic Cooperation and Development countries, "The Alberta Government is responding to these international forces for change by building upon the Alberta Advantage" (Hyndeman, Holly, \& Macdonald, 1996, p. 2) Alberta's "advantage" in industrial electricity rates, for instance, consists of a rate roughly equivalent to one-third that of California's. The impact of the North American Free Trade Agreement (NAFTA) is evident in the fact that Alberta measures its "advantage" primarily in relation to states within the United States. Moreover, the beliefs of Alberta's opponents to federal regulations on GHG emissions, which were echoed by other sectors and provinces prior to Kyoto, are predictive as well as prescriptive. Figure 1, taken from an Alberta Energy Department publication, claims that "global forces [are] moving everyone towards deregulation." 
Figure 1

Global Forces Moving Everyone Towards Deregulation

Agriculture?

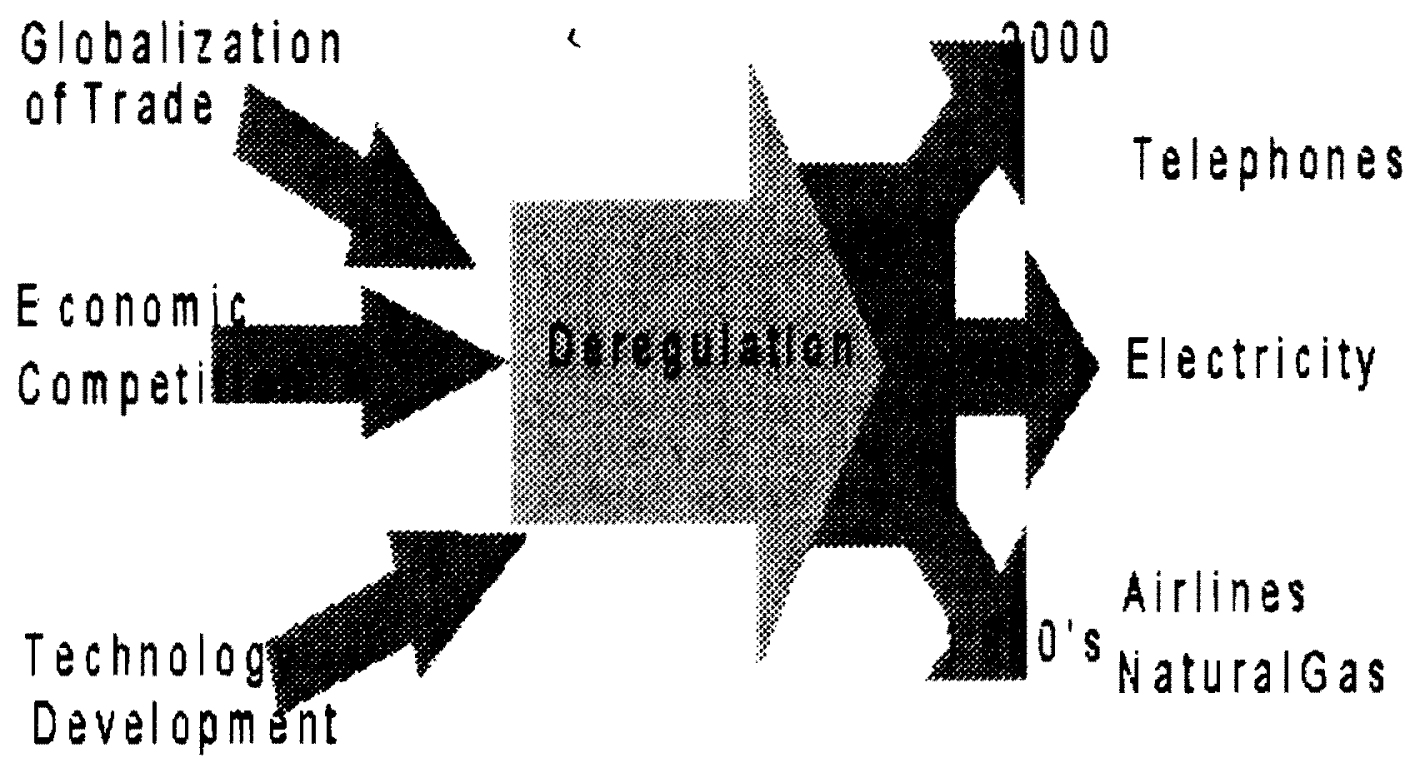

In the face of economic globalization and the related effects of NAFTA, provincial actors and "local" industries have come to see themselves as global actors. Thus, they believe that the federal government should not be an international leader in reducing GHG emissions, but rather should "provide a competitive infrastructure to attract investment" (Hyndman et al., 1996, p. 2). Given that $80 \%$ of Canada's exports go to the United States, a key concern therefore was what the U.S. climate change position at Kyoto would be (Interview with John Dillon, Climate Change Coordinator, Business Council on National Issues, December 8, 1997 [Ottawa]).

By the time that Canada's energy and environment ministers met on November 12, 1997, the United States had announced its plan to push for stabilizing GHG emissions at 1990 levels by 2012 and its determination to see developing countries commit themselves to controlling emissions. Prime Minister Jean Chrétien pledged that Canada would "do better than the U.S." (quoted in Knox, 1997), but no Canadian position was announced until the Kyoto Conference. At the November 12 meeting, the energy and environment ministers agreed only to stabilize emissions at 1990 levels by 2010 -virtually the same as the U.S. stance. Yet, with the opening of the Kyoto conference, the federal government announced its commitment to reduce emissions by $3 \%$ by 2010 , and an additional $5 \%$ by 2015 , attempting to position itself as a middle man between the United States and Europe in the talks (Government of Canada, 1997, p. 1). 
The proposal may have made Canada look greener than the United States, but it was met with bitter criticism from some of the provinces. Alberta's Energy Minister declared bluntly, "They've betrayed the process" (Mcilroy \& Laghi, 1997, p. 1). Nonetheless, Canada joined forces with the United States to push for a clause in the treaty that will make it possible for countries to deduct the amount of carbon dioxide stored in sinks, such as through reforestation efforts, from their net GHG emissions. In the end, largely because of European intransigence, the parties agreed to reduce overall emissions by at least $5 \%$ below 1990 levels in the commitment period 2008 to 2012 (Kyoto Protocol, Article 3). The ink was barely dry on the treaty when the provinces made it clear that, given their sense of betrayal, implementation would be difficult, even as American senators threatened to veto ratification because the Kyoto Protocol did not commit developing countries to binding targets.

\section{Analysis and Conclusions}

This study of Canadian climate change policy during the decade following 1988 offers an opportunity to examine the dynamics of a globalized interpretation of the ACF. Both the environmental and the industry advocacy coalitions are easily identifiable in terms of their core beliefs, which included globalized economic, political, and even scientific understandings (see Table 1). The environmentalists' core beliefs were based upon primarily causal beliefs about the

\section{Table 1}

The Advocacy Coalition Framework Applied to the Canadian Climate Change Policy Process

\begin{tabular}{|c|c|c|}
\hline $\begin{array}{l}\text { Elements } \\
\text { of ACF }\end{array}$ & $\begin{array}{l}\text { Environmental } \\
\text { Coalition }\end{array}$ & $\begin{array}{l}\text { Industrial } \\
\text { Coalition }\end{array}$ \\
\hline Key membership & $\begin{array}{l}\text { NGOs, Dept. of } \\
\text { Environment, some } \\
\text { scientists }\end{array}$ & $\begin{array}{l}\text { Fossil fuel industry, } \\
\text { Natural Resources } \\
\text { Canada, Alberta, } \\
\text { Business Council }\end{array}$ \\
\hline $\begin{array}{l}\text { Primary causal } \\
\text { beliefs }\end{array}$ & $\begin{array}{l}\text { Real threat of climate } \\
\text { change (IPCC); } \\
\text { unsustainability of } \\
\text { current economic practices; } \\
\text { global competitiveness } \\
\text { requires technological } \\
\text { change }\end{array}$ & $\begin{array}{l}\text { Costliness of reducing } \\
\text { GHG emissions; } \\
\text { skepticism of IPCC } \\
\text { findings; global } \\
\text { competitiveness } \\
\text { requires not going } \\
\text { faster than the United } \\
\text { States }\end{array}$ \\
\hline $\begin{array}{l}\text { Primary moral } \\
\text { beliefs }\end{array}$ & $\begin{array}{l}\text { Precautionary principle; } \\
\text { special responsibility } \\
\text { of high per capita } \\
\text { emitters; need for } \\
\text { additional aid for } \\
\text { developing countries }\end{array}$ & $\begin{array}{l}\text { Primacy of prosperity } \\
\text { and competitiveness; } \\
\text { need for industrialized } \\
\text { countries to act first; } \\
\text { equity for resource- } \\
\text { dependent provinces }\end{array}$ \\
\hline
\end{tabular}


Symposium on Canadian Environmental Policy: Litfin

planet's climate systems, drawn largely from the analytical knowledge supplied by the IPCC, and moral beliefs about Canada's special responsibility as a high per capita polluter (Environment Canada, 1995; Government of Canada, 1991). The environmental coalition consisted primarily of NGOs acting both domestically and internationally, but also included some scientists and individuals from Environment Canada. The industry coalition was centered in the provinces and sectors that would be affected most strongly by reductions in GHG emissions, with energy-rich Alberta playing the most outspoken role. Its core beliefs included an understanding of global economic forces moving local and regional actors toward deregulation (and hence away from federal strategies to regulate GHG emissions), some skepticism regarding scientific predictions of climate change, and perhaps a generalized moral belief in the primacy of short-term economic welfare over long-term environmental objectives. Thus, the core beliefs and selfunderstandings of both advocacy coalitions were not only enduring, as the ACF would anticipate, but had a strong global component. Neither their identities nor their actions can be understood fully within either a solely domestic or a solely international context. Rather, the advocacy coalitions operated along the domesticforeign frontier, which leads to an expanded conceptualization of the ACF.

Moreover, the ACF's emphasis on the advocacy use of analysis is directly on target for the Canadian climate change debates. The climate change issue was placed on the international agenda initially by scientists, and was defined technically through the IPPC's regular reports. Thus, two of the three conditions for policy learning across coalitions were present: an analytically tractable issue (despite the presence of significant uncertainties) and the presence of a professionalized forum. Nonetheless, given the highly conflictual nature of the climate change issue, which cuts to the heart of the habits of industrial society, it is not surprising that neither of the coalitions was led to alter their core beliefs. Rather, the IPCC reports were highly politicized, with the environmental coalition emphasizing the high risks and more alarming conclusions and the industrial coalition emphasizing the scientific uncertainties. Thus, as the ACF would predict, rather than altering their core beliefs, the advocacy coalitions simply fit the scientific findings into their belief systems. Yet because the scientific bases for the climate change policy debates were the findings of an international body, the IPCC, a purely domestic application of the ACF would be short-sighted. Again, both coalitions were acting along the domestic/foreign frontier in their advocacy uses of knowledge.

Canadian climate change policy formulation is also consistent with the ACF's claim that policy outcomes are constrained by stable system parameters. The two "Canadian conundrums" that circumscribed the climate change policy debates were Canada's unique constitutional arrangement, which confers substantial environmental authority on the provinces, and Canada's relationship to the dominant player in the global economy, the United States. Significantly, the dynamics of globalization tend to reinforce both of these structural constraints. Because of their close ties to and dependence upon industry, the provinces are likely to experience the effects of globalization most acutely. This is one aspect of what was referred to earlier as "glocalization." A typical example is the Alberta Energy Department's understanding of itself as a global actor, constrained by global forces. Similarly, in an increasingly globalized economy, which includes the effects of NAFTA, Canada is likely to be all the more sensitive to developments in the United States. Thus, whereas Canada castigated the United States at Rio for the latter's intransigence, 5 years later it waited to hear the U.S. 
position before formulating its own stance-which was only slightly "greener" for symbolic purposes.

But perhaps Canada's position at Rio was merely rhetorical, and there was no policy shift at all. There is some validity to this perspective, since the structural constraints mentioned above very well may have prevented Canada's federal government from promoting any binding restrictions on GHGs at Rio in the absence of provincial consent and a similar U.S. commitment. Nonetheless, this interpretation cannot explain why the federal government adopted a stance of international leadership at Rio, particularly since it also was a strong advocate of binding restrictions on GHG emisssions. Apparently, the federal government was responding to its own electoral incentives, dictated by an intensely proenvironment public between 1988 and 1992. Moreover, there also is evidence that the federal government, most specifically Environment Canada, was sincere in its environmental beliefs, and not merely playing to public opinion (see Govemment of Canada, 1991). So, while there was no actual policy shift, since the Rio position was more a statement than a policy, there was a reorientation. That reorientation is explainable largely in terms of the impact of economic globalization on the two structural parameters constraining Canadian climate change policy: the federal/provincial division of authority and the influence of the United States.

Could all of this be explained on the basis of ordinary interest-driven politics? Is not Canada's weak position on climate change what one would expect from a heavily energy-dependent country, especially one with powerful provinces allied with the fossil fuel industry? Clearly, a pure interest-based politics would have trouble explaining Canada's initial leadership at Rio; nor could it explain the character and the impact of the environmental coalition. The ACF, unlike interest-based accounts of the policy process, highlights the role of scientific knowledge. Despite the uncertainties, the IPCC consensus, which is not reducible to interests, laid the basis for the climate change negotiations. Even the industrial coalition's position, it should be noted, is not wholly reducible to interests since it is also rooted in causal beliefs about the costliness of reducing GHG emissions. As the COGGER study cited earlier suggests, achieving small reductions in GHG emissions may even be cost-effective (Robinson et al., 1993). So the ACF's emphasis on beliefs and the advocacy use of knowledge is quite helpful in shedding light on the Canadian climate change policy process.

Finally, the question remains as to why we should turn to the frontier rather than simply interpreting federal climate change policy as a two-level game. After all, Canada's federal government seems to be an example par excellence of a state caught between the exigencies of domestic and international politics. Indeed, this approach could yield a plausible account, but it would not go far enough because it suggests merely the interplay between separate levels of politics, rather than their convergence; two-level games cannot account for the globalized selfunderstandings of the key actors. In the case of Canadian climate change policy, the boundaries between political levels are blurred, as local and provincial actors increasingly understand themselves as players in a global game. "Local" economic actors, pressed by deregulation and the exigencies of competitiveness, understand their identities and interests in global terms. Similarly, environmental NGOs find themselves acting at all political levels-provincial, federal, international-with their belief systems formulated in terms of global scientific understandings and ethical notions of planetary responsibility. The state, therefore, should not be regarded as the gatekeeper between distinct domestic and foreign levels of analysis, 
as two-level games would have it, but rather as a point of convergence or even a battleground for forces operating along the domestic-foreign frontier.

The dynamics of Canadian climate change policy formulation are described best in terms of the frontier, challenging the notion of the unitary nation-state actor that until recently has divided the worlds of policy studies and international relations. A globalized understanding of the ACF therefore can help to build a bridge between these "two solitudes." If a wide range of advocacy coalitions is being globalized, and there is good reason to believe they are, the implications for long-term ecological sustainability are far from clear. Much will depend upon their power and persuasiveness.

\$*

Karen T. Litfin is associate professor of political science at the University of Washington. She is author of Ozone Discourses: Science and Politics in Global Environmental Cooperation (Columbia University Press, 1994).

\section{Notes}

I am grateful to Beth Schaefer Caniglia, Kathryn Harrison, George Hoberg, Jonathan Kruegger, Peter May, Matthew Paterson, Paul Sabatier, and Granville Sewell for their helpful tips and comments.

${ }^{1}$ I am indebted to Kathryn Harrison for this observation.

\section{References}

Atkinson, K. (1994). The Canadian Arctic and global climate change. In K. Atkinson \& A. T. McDonald (Eds.), Environmental issues in Canada (pp. 67-86). Ouawa, ON: Centre for Canadian Studies.

Canadian Council of Ministers of the Environment. (1990). National action strategy on global warming. Winnipeg, MB: Canadian Council of Ministers of the Environment.

Climate Action Network. (1997, December 2). I'm a lumberjack and I'm OK? Eco Newsletter, pp. $1-4$.

Doem, B., Pal, L., \& Tomlin, B. (Eds.). (1996). Border crossings: The internationalization of Canadian public policy. Toronto, ON: Oxford University Press.

Dyer, H. (1994). Environmental ethics and intemational relations. Paradigms, 8(1), 58-77.

Environment Canada. (1995). National action program on climate change. [On-line]. Available: http://www.ec.gc.ca/climate.resource/cnapcc. Ottawa, ON: Department of Environment.

Environment Canada. (1997). Intemational action on climate change: The road to Kyoto. Green Lane, p. 3. [On-line]. Available: hup://www.ec.dc.ca/climate/fact.action.html.

Evans, P. B., Jacobson, H. K., \& Putnam, R. D. (Eds.). (1993). Double-edged diplomacy: International bargaining and domestic politics. Berkeley, CA: University of Califomia Press.

Gourevitch, P. (1978). The second image reversed: The intemational sources of domestic politics. International Organization 32(4), 881-811.

Government of Canada. (1991). The state of Canada's environment. Ottawa, ON: Government of Canada.

Government of Canada. (1997). Canada propases largets for reductions in greenhouse gas emissions. (News Release) [On-line]. Available: hup://canada.gc.ca/cc/position_n_e.htm.

Harrison, K. (1996). Passing the buck: Federalism and Canadian environmental policy. Vancouver, BC: University of British Columbia Press.

Hoberg, G. (1996), Goveming the environment: Comparing Canada and the U.S. In K. Banting, G. Hoberg, \& R. Simeon (Eds.), Degrees of freedom: Canada and the United States in a changing world (pp. 341-385). Montreal: McGill-Queen's University Press.

Hoberg, G., \& Harrison, K. (1994). It's no easy being green: The politics of Canada's green plan. Canadian Public Policy, 20(1), 119-137.

Hyndman, R., Holly, C., \& Macdonald, D. (1996). Restructuring, climate change and the role of renewables. Paper presented at the 12th Annual Conference of the Canadian Wind Energy 
Association, October 6-9, Ottawa, ON [On-line]. Available: http://borg.energy.gov.ab.ca/env/restr.homl.

Intergovermmental Panel on Climate Change. (1995). Climate change 1995. Oxford: Oxford University Press.

Intergovernmental Panel on Climate Change. (1995). Climate change 1995. Oxford: Oxford University Press.

Jenkins-Smith, H., \& St. Chir, G. K. (1993). The politics of offshore energy: Empirically testing the advocacy coalition framework. In P. Sabatier \& H. Jenkins-Smith (Eds.), Policy learning: An advocacy coalition approach (pp. 149-176). Boulder, CO: Westview.

Katzenstein, P. J. (1983). Small stales in world markets: Industrial policy in Europe. Ithaca, NY: Comell University Press.

Knox, P. (1997, November 20). The world confronts global warming: Canadu limps into Kyoto arena. Toronto Globe and Mail [On-line]. Available: www.theglobeandmail.com/docs/news/19971 128/TheWorld/ UWARMN.huml.

Lipschutz, R. D. (1996). Global civil society and global environmental governance: The politics of nature from place to planet. Albeny, NY: State University of New York Press.

Litfin, K. T. (1997). Sovereignty in world ecopolitics. Mershon International Studies Review, 4I(2), 167-205.

Litfin, K. T. (Ed.). (1998). The greening of sovereignly in world politics. Cambridge, MA: The MIT Press.

Mcilroy, A., \& Laghi, R. (1997, December 2). Otuwa changes gas target. Toronto Globe and Mail, p. 1.

Mintrom, M., \& Vergari, S. (1996). Advocacy caalitions, policy entrepreneurs, and policy change. Policy Studies Jownal, 24(3), 420-434.

NGOs urge ministers to abandon harmonization. (1996, May 31). Eco-Log Week, pp. 1-4.

Nickerson, C. (1997, November 29). Canada's green image hides grim environmental reality. Seatlle Post-Intelligence. p. All.

Paterson, M. (1996). Global marming and global politics. London: Routledge.

Putnam, R. D. (1988). Diplomacy and domestic politics: The logic of two-level games. International Organization, 42(3), 427-460.

Richardson, R. (1993). Government greenwash: Pass an environmental law, then forget it. The Canadian For wom, 72(1), 11-15.

Robinson, J., et al. (1993). Canadian options for greenhouse gas emissions reduction. Otawa, ON: Canadian Global Change Program.

Robertson, R. (1995). Glocalization: Time-space and homogeneity-heterogeneity. In M. Featherstone, S. Lash, \& R. Robertson (Eds.), Global modernities (pp. 25-44). Thousand Oaks, CA: Sage.

Rosenau. J. N. (1997). Along the domestic-foreign frontier: Exploring governance in a turbulent world. Cambridge: Cambridge University Press.

Sabatier, P. A. (1988). An advocacy coalition framework of policy change and the role of policyoriented leaming therein. Policy Sciences, 21(2), 129-168.

Sabatier, P. A. (1993). Policy change over a decade or more. In H. Jenkins-Smith \& P. Sabatier (Eds.), Policy learning: An advocacy coalition approach (pp. 13-40). Boulder, CO: Westview.

Sabatier, P. A., \& Jenkins-Smith, H. C. (Eds.). (1993). Policy change and learning: An advocacy coalition approach. Boulder, CO: Westview.

Schneider, S. H. (1989). Global warming: Are we entering the greenhouse centwry? San Francisco, CA: Sierra Club Books.

Schreurs, M., \& Economy, E. (Eds.). (1997). The internationalization of domestic environmental policy. Cambridge: Cambridge University Press.

Sierra Club of Canada. (1997). Rio report card, federal 1997 [On-line]. Available: http://www.sierraclub.ca/national/rio/nio97-federal.html.

Valpy, M. (1997, November 18). If the provinces approve. Toronio Globe and Mail [On-line]. Available: hup://www.theglobeandmail.com/docs/news/19971118/Column/7Valpy.html.

Wapner, P. (1996). Environmental activism and world civic politics. Albany, NY: State University of New York Press. 